\title{
REHABILITATION OF GESTATIONAL POSSIBILITIES OF ENDOMETRIUM IN WOMEN WITH A HISTORY OF PREGNANCY LOST
}
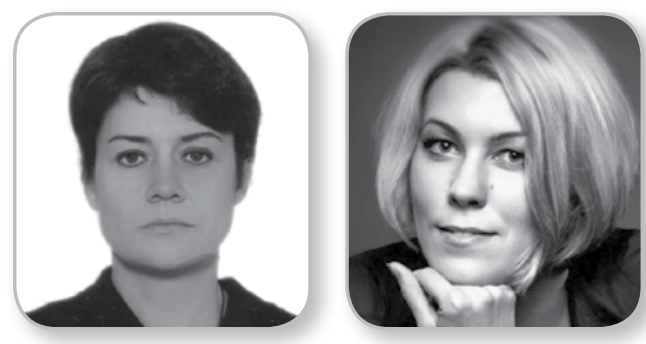

L.N.Semeniuk, N.M.Voronkova, O.V.Larina

Ukrainian Research and Practical Centre of EndocrineSurgery, Transplantation of Endocrine Organs andTissues of the Ministry of Health of

Ukraine, Kyiv, Ukraine

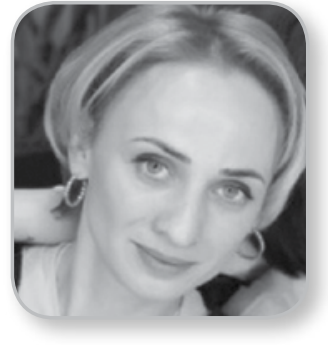

INTRODUCTION

The issues of maternal and child health are among the priorities of modern health care [1]. Nowadays all civilized countries conduct a wide range of researches aimed at studying the causes of human reproductive dysfunction as well as developing methods for restoring fertility.

Endometrium is the key structure for implantation, which is a complex process of integrating and exchanging signals between embryonic and decidual endometrial cells $[2,3]$. And this structure is often damaged by the influence of endometrial infection.

Chronic endometritis is a clinical and morphological syndrome characterized by complex morphological and functional changes in the endometrium of inflammatory origin, leading to disruption of the cyclic transformation and tissue receptivity $[2,4]$. Inflammation process that occurs in the inner membrane of the uterus may be regarded as chronic when the duration of the disease is two months or more [2]. The frequency of chronic endometritis according to different authors varies from 2 to $73 \%[1,2]$, while the maximum frequency falls on the age group of 26-35 year olds $[1,3]$.

In modern terminology chronic endometritis is characterized by a change in the etiological structure with an increase in the importance of viral and pathogenic microorganisms, increasing the mixed infections, as well as the growth of microorganisms, resistant to pharmacological therapy $[2,5,6]$.

Objective: To improve methods of prevention, diagnosis, and treatment of patients with early reproductive loss in anamnesis.

\section{MATERIALS AND METHODS}

Studies were conducted in the endometrium of women of reproductive age with early reproductive loss in history (4-12 weeks) when planning pregnancy. The work was performed in the gynecological department of the hospital № 18 in Kiev and Ukrainian Scientific and Practical Center of endocrine surgery, endocrine transplantation of organs and tissues of the Ministry of Health of Ukraine, Kiev. The studies were conducted during 2010-2017 in preparation for the subsequent pregnancy, carried out to evaluate the anti-inflammatory therapy after excluding violations of hormonal, genetic diseases and at least 3 months after the termination of the last pregnancy. Ultrasound examination of the pelvic organs, histological and microbiological examination of the endometrium was performed on 7-10th and 21-24th days of the menstrual cycle.

A contingent of studies was determined by a retrospective analysis of the medical history of 360 women with spontaneous abortion in gestational age from 5 to 12 weeks. Depending on the form of termination of pregnancy, groups were selected: 1 $(n=72)$ anembryonia, $2(n=192)$ embryo lysis, $3(n=96)$ frozen pregnancy on a background of inflammatory process in the uterus. The control group consisted of 30 patients with artificial abortions, planning a pregnancy in the future.

Methods of investigation: Research methods: clinical and statistical analysis, pathomorphological examination of the endometrial biopsy, microbiological examination of the uterine cavity, ultrasound examination of the pelvic organs. Statistical processing of results was obtained using statistical software 
package Statistica v.6.0. and Microsoft Office Excel 2003.

\section{RESULTS AND DISCUSSION}

As a result of a retrospective analysis of the histological examination of 100 female scrapers, various abnormalities in the development of pregnancy in the early period were noted. In group 1 with anembryonia: chorionic villi characterized by a sharp increase in the number of microvilli, the presence of avascular station, the absence of hemorrhage in the stroma of the villi. In the intervillaceous space, a decrease in proliferative activity, partial fibrinoid degeneration of the trophoblast. There were areas of degeneration of decidual cells, isolated foci of hemorrhage. The spongy layer is an elongation of the gland lumen. Lymphocytic infiltration of leucocytes (fig. 1).

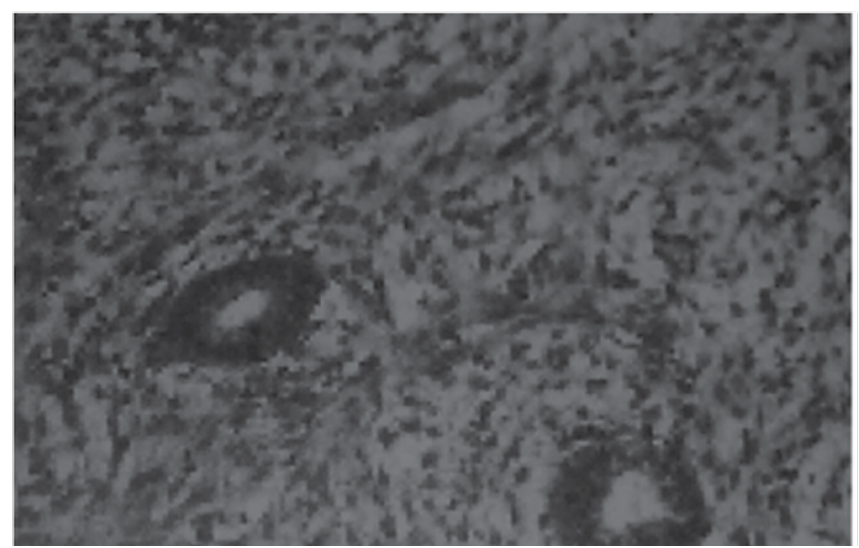

Fig. 1. Lymphocytic infiltration in the stroma of the endometrium.

In the second group, there was a disappearance of chorionic villi, their edema, fibrosis, lack of circulation in the stroma of the villi. Multiple fibrinoid degeneration of

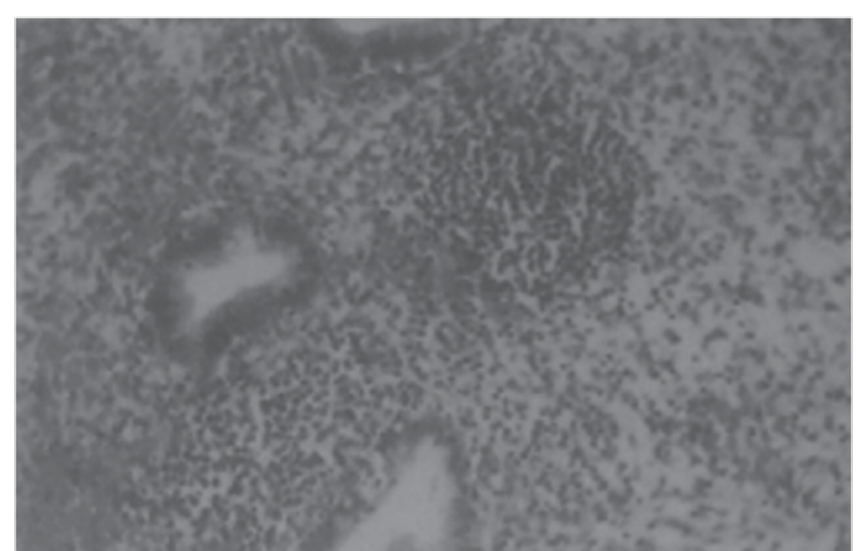

Fig. 2. Lymphoid histiocytic infiltration of the stroma of the endometrium. trophoblast was noted, which reduced its proliferative activity.

Along with decidual tissue degeneration, decidual cells, areas of necrosis and hemorrhage and fibrinoid necrosis of the walls of the vessels with edematous phosphocytosis of various degrees were observed. Massive filtration of leukocytes of decidual tissue was characteristic for histological screening of the third group, as well as multiple micro-abscesses with spreading into the spongy layer of the endometrium, which clearly indicates the ascending pathway of infection.

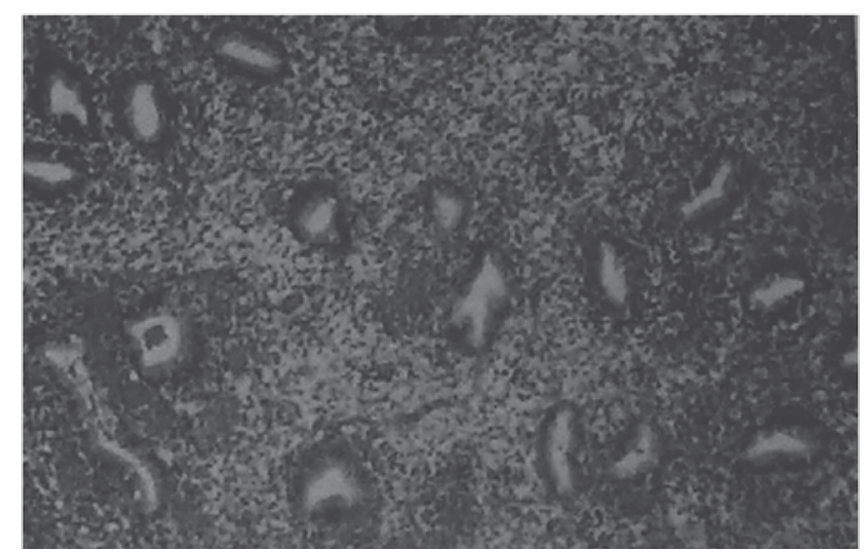

Fig. 3. Lymphoid-plasmacytic infiltration of the stroma of the endometrium.

In the control group, a compact layer of the endometrium is represented mainly by parietal decidual cells of an intermediate type. In 12 (40\%) cases, there were degenerative changes in decidual cells of the lymphoid elements of the cluster and focal edema of the stroma in 2 (6.7\%) cases.

Atthestageofpreparationforpregnancy, anultrasound evaluation of the structure of the endometrium in 100 women was carried out. Among them in 1 group there were 17 women with anembryonia in the anamnesis. The sonographic structure of the endometrium had some peculiarities: in $13(76.47 \%)$ cases it satisfied the normal criteria for the 1st and 2 nd phases of the menstrual cycle. Four women at the first stage had a hyperechoic structure of the basal layer, a decrease in the thickness of the endometrium (up to $6.3 \mathrm{~mm}$ ) in the 2nd phase of the menstrual cycle, and asymmetry of the anterior and posterior endometrium (23.5\%).When in the proliferative phase, dopplerometry revealed a decrease in vascular resistance ( $R$ \& $D$ from 0.9 to 0.7 , $\mathrm{PI}<3$ ), according to the phase of the change cycle and the end diastolic flow rate. The number of myometric 
movements per minute was about $3(2.89 \pm 1.2)$.

Among patients in the 2 nd group $(n=38)$, of them in 25 women $(65.8 \%)$ ultrasound revealed the following changes: endometrial thickening with increased echogenicity in the proliferative phase, uneven endometrial contour, hyperechoic inclusions in the basal layer, uneven expansion of the uterus with the help of a hypoechogenic component. In 13 (34.2\%) patients no pathology was revealed. The features of dopplerometric indicators in this group were a reduced blood flow in 25 (65.8\%) cases, the absence of early diastolic notch and diastolic blood flow in the uterine arteries in 15 (39.47\%) cases, high values of vascular resistance index $(\mathrm{PI} \geq 3, \mathrm{IR}>0.79)$ in $32(84.21 \%)$ patients. The number of myometrial contractions per minute was 2-3 (2.34 \pm 0.36$)$.

In group 3, where the abortion was performed on the infectious-inflammatory background $(n=45)$, heterogeneous structure of the endometrium and its combination with thinning of the M-echo, gaseous bubbles in the uterine cavity, irregular contour of the endometrium, hyperechoic inclusions in the basal layer were observed. Asymmetry of the thickness of the anterior and posterior walls of the endometrium was noted in combination with M-echo heterogeneity in 12 patients (26.7\%), endometrial thinning in 6 (10.90\%), uneven uterine dilatation in the proliferative phase. In 4 (8.9\%) patients there was no pathology of the endometrium revealed. The features of dopplerometric indicators in this group were a reduced blood flow in 28 $(62.2 \%)$ cases, the absence of early diastolic notch and diastolic blood flow in the uterine arteries in 19 (42.2\%), high values of vascular resistance index $(\mathrm{PI} \geq 3 ; \mathrm{IR}>0.79)$ in $36(80.0 \%)$ patients. The number of myometrial contractions per minute was 1-2 (1.54 \pm 0.86$)$.

All patients underwent bacteriological and PCR studies of aspiration materials from the uterus. Conditionally pathogenic microorganisms in $24.2 \%$, a combination of mycoplasma and ureaplasma in $15.2 \%$, a combination of mycoplasma, ureaplasma and viruses in $12.1 \%$, aerobic-anaerobic associations in $12.1 \%$, a combination of chlamydia and viruses in $61 \%$ cases were revealed.

Histological examination of the endometrium at the stage of preparation for pregnancy revealed a violation of proliferative processes in almost all women of the 1st group. Among women of 2nd group 7 (18.42\%) had disturbed proliferative processes in endometrium, 12 (31.57\%) micro-polyps, 6 (15.78\%) endometrium in different phases of maturation, 23 (60.52\%) infiltration of lymphocytes, 1 (2.63\%) necrotic tissue, 3 (7.9\%) plasma cells and lymphoid follicles in the basal and functional layers, 1 (2.63\%) focal stromal fibrosis, sclerosis of the spiral artery walls.

In patients of the third group, some changes in the endometrium were detected: disturbance of the maturation phases in 15 (33.3\%), lymphocyte infiltration in 24 (53.3\%), necrotic tissue in $3(6.7 \%)$, plasma cells and lymphoid follicles in the basal and functional layers in $10(22.2 \%)$, focal fibrosis of the stroma in $13(28.8 \%)$, sclerosis of the walls of the spiral arteries in 15 (33.3\%).

The study allowed to conduct etiopathogenetic treatment based on the changes revealed in each case. Patients with a predominance of viral and infectious factors were given injections of the immunomodulator into the uterine cavity up to 5 $\mathrm{ml}$ every 2 days, No. 5. The choice of drug groups depended on the microbiological study and on the microbial composition of the uterine cavity, which was an indication for the use of antibacterial drugs. At the end of anti-inflammatory and immunomodulatory therapy, the microflora of the genital tract was restored by topical administration of probiotics for 3 weeks. The total duration of therapy was 4 weeks. Cyclic hormone therapy or only dydrogesterone in the II phase of the cycle is successfully carried out with duration of 2-3 cycles. 2 months after the treatment the control of its efficiency was carried out. The criteria for the treatment efficiency were the following:

- relief of clinical symptoms;

- restoration of echographic picture of the endometrium;

- elimination of pathogenic organisms from the uterus;

- restoration of normal morphological structure of the endometrium.

In all patients who received complex antiinflammatory therapy, at the end of treatment, the flora in the uterine cavity was not detected. In the last cycle, the state of the endometrium was evaluated (ultrasound and hemodynamic dopplerometry of the uterus).

As a result, the frequency of detection of the treatment compliance with the endometrial echographic structure in the secretory phase of the cycle was brought to the values of control indices of healthy women of childbearing age. The indication for the recommended pregnancy in the examined women was the determination in the ovulatory period 
of the three-layered structure of the endometrium, the presence of a "peristaltic wave" directed to the uterine fundus and the thickness of the endometrium of at least $8 \mathrm{~mm}$.

Evaluation of fertility recovery was conducted 6 months after the examination and the treatment. The frequency of occurrence and progression of pregnancy over 12 weeks in the 1 st group was $5(29.41 \%)$ cases compared to $18(47.36 \%)$ in group 2, $15(33.3 \%)$ in group 3.

Our results prove a high percentage of chronic inflammation in the uterine cavity in patients with early reproductive losses. Thus, it can be seen from the analysis that the success of future pregnancies in women with a history of pregnancy loss depended on the severity of inflammatory changes in the endometrium, both during the termination of pregnancy and at the stage of pregravid.

\section{CONCLUSIONS}

Chronic endometritis is a clinical and morphological syndrome, which is detected by ultrasonic criteria, and morphological pattern is equally important.

Hysteroscopy can be considered as the final diagnostic method for establishing the pathology of the endometrium.

The result of hysteroscopic, microbiological, and ultrasound studies can personalize therapeutic tactics in each case.

The conducted morphological studies demonstrated high informative value of endometrial biopsy in the diagnosis of endometrial pathology.

\section{REFERENCES}

1. Radzinskiy $V E$, et al. [Non-developingpregnancy. Method.recommendationsMARS. Version 1.0]. M: StatusPraesensJourmal; 2015. 48 p. [Russian].ISBN 978-5-905796-73-9

2. Sidelnikova VM. [Preparation andmaintenanceof pregnancyin womenwithrecurrent miscarriage: methodologiesand clinicalprotocols]. M: MEDpressInform; 2011. 216p.[Russian].

3. Sukhikh GT, Shurshalina AV. [Chronic endometritis]. M: "GEOTAR-Media"; 2010.64 p.[Russian].

4. Fedorina TA, Lineva Ol, SizovaNV, Filippova TYu. [Morphological criteria ofpathogenetic variants of unspecified abortions]. Akusherstvoiginekologiya. 2006;(4): 31-34.[Russian].

5. Adegboyega PA, Pei Y, McLarty J. Relationship between eosinophilsand chronicendometritis. HumPathol. 2010 Jan;41(1):33-7.
6. Practice Committee of the American Society for Reproductive Medicine. Evaluation and treatment of recurrent pregnancy loss: a committee opinion. FertilSteril. 2012 Nov; 98(5):1103-11.

\section{ЛITEPATУРA}

1. Неразвивающаяся беременность. Методические рекомендации МАРC (Междисциплинарной ассоциации специалистов репродуктивной медицины) / [авт.-сост. В.Е. Радзинский и др.]. М.: Редакция журнала StatusPraesens, 2015. - 48 с. ISBN 978-5-905796-73-9

2. Сидельникова В.М. Подготовка и ведение беременности у женщин с привычным невынашиванием. Методические пособия и клинические протоколы / В.М. Сидельникова. М.: МЕДпресс-Информ, 2011. - 216 с.

3. Сухих Г.Т. Хронический эндометрит / Г.Т. Сухих, А.В. Шуршалина. - М. «ГЭОТАР-Медиа», 2010. - 64 C.

4. Морфологические критерии патогенетических вариантов неуточненных абортов /. Т.А. Федорина, О.И. Линева, Н.В. Сизова, Т.Ю. Филиппова // Акушерство и гинекология. - 2006. - №4. - C.31-34.

5. Adegboyega P.A. Relationship between eosinophilsandchron icendometritis / P.A. Adegboyega, Y. Pei, J. McLarty // Hum. Pathol. 2010. - Vol. 41, N. 1. - P. 33-37.

6. Оценка и лечение рецидивирующей потери беременности: точка зрения комитета / Практический комитет Американского общества репродуктивной медицины // Fertil. Steril. - 2012. - Vol. 98, N.5. - P. 1103-1111. [PMD: 22835448]

\section{PEЗЮME \\ Реабілітація гестаційних можливостей ендометрія у жінок із невиношуванням вагітності в анамнезі \\ Л.М.Семенюк, Н.М.Воронкова, О.В.Ларіна}

Мета дослідження - поліпшити методи профілактики, діагностики та лікування хворих 3 ранніми репродуктивними втратами в анамнезі.

Матеріали та методи. Протягом 2010-2017 рр. проводилось дослідження ендометрія жінок репродуктивного віку з ранньою репродуктивною втратою в анамнезі (4-12 тижнів). У процесі підготовки до наступної вагітності проведена оцінка протизапальної терапії після виключення гормональних порушень, генетичних захворювань і принаймні через 3 місяці після закінчення 
останньої вагітності. Ультразвукове дослідження органів малого тазу, гістологічне та мікробіологічне дослідження ендометрія проводили на 7-10 та 21-24 дні менструального циклу. Контингент для участі в дослідженні визначався ретроспективним аналізом історій хвороб 360 жінок із спонтанним абортом у гестаційному терміні від 5 до 12 тижнів. Залежно від форми припинення вагітності виділені групи: $1(n=72)$ - анембріонія, 2 ( $n=192)$ - лізис ембріону, 3 (n=96) - завмерла вагітність на тлі запального процесу в матці. Контрольну групу склали 30 пацієнтів з штучними абортами в анамнезі, які планували вагітність.

Результати та обговорення. В результаті ретроспективного аналізу гістологічного дослідження зіскобів у жінок відзначали різні порушення в розвитку вагітності на ранньому періоді.На стадії підготовки до вагітності проводили ультразвукову оцінку структури ендометрія у 100 жінок. Серед них в 1 групі було 17 жінок, які мали анембріонію у анамнезі. Сонографічна структура ендометрія мала деякі особливості: у 13 (76,47\%) випадках вона відповідала нормативним критеріям 1-ї та 2-ї фаз менструального циклу. Чотири жінки на першому етапі мали гіперехогенну структуру базальногошару,зменшеннятовщиниендометрія(до 6,3 мм) у 2-й фазі менструального циклу та асиметрію (23,5\%).У всіх пацієнток проведені бактеріологічні та ПЛР-дослідження аспіраційних матеріалів 3 матки. Умовно-патогенні мікроорганізми виявлені у 24,2\%, комбінація мікоплазм і уреаплазм - у 15,2\%, комбінація мікоплазм, уреаплазм та вірусів -у 12,1\%, аеробно-анаеробні асоціації - у 12,1\%, комбінація хламідій та вірусів - у 61\% випадків. Дослідження дозволило проводити етіопатогенетичне лікування на основі змін, виявлених у кожному конкретному випадку. Хворим із переважанням вірусних та інфекційних факторів вводили імуномодулятор в порожнину матки до 5 мл кожні 2 дні, № 5. Вибір антибактеріальних препаратів залежав від даних мікробіологічного дослідження. Після закінчення протизапальної та імуномодуляторної терапії мікрофлора статевихшляхів була відновлена шляхом введення пробіотиків протягом 3 тижнів. Загальна тривалість терапії становила 4 тижні. Циклічна гормональна терапія або тільки дидрогестерон у II фазі циклу проводилися протягом 2-3 циклів. Через 2 місяці після лікування проводився контроль його ефективності. У всіх пацієнтів, котрі отримали комплексну протизапальну терапію, наприкінці лікування флора в порожнині матки не була виявлена. У останньому циклі оцінювали стан ендометрія (ультразвукова та гемодинамічна доплерометрія матки). У результаті частота виявлення відповідності ендометрія ехографічній структурі при секреторній фазі циклу була доведена до значень контрольних показників здорових жінок дітородного віку. Оцінка відновлення фертильності проводилася через 6 місяців після обстеження та лікування. Частота виникнення та прогресування вагітності протягом 12 тижнів у 1-й групі становила 5 (29,41\%) випадків у порівнянні $318(47,36 \%)$ у групі 2, $15(27,27 \%)$ в 3 групі жінок.

Висновки. Хронічний ендометрит $\epsilon$ клінікоморфологічним синдромом, який виявляється ультразвуковими критеріями, та морфологічна картина $\epsilon$ також важливою частиною діагностики. Гістероскопія може розглядатися як остаточний діагностичний метод встановлення патології ендометрія. Наші результати показують високий відсоток хронічного запалення в порожнині матки у пацієнтів з ранніми репродуктивними втратами. Результати гістероскопічних, мікробіологічних та ультразвукових досліджень можуть індивідуалізувати терапевтичну тактику. Проведені морфологічні дослідження продемонстрували високу інформативну цінність біопсії при діагностиці патології ендометрія.

Ключові слова: втрата вагітності, ендометрій, гестація.

\section{SUMMARY \\ Rehabilitation of gestational possibilities of endometrium in women with a history of pregnancy lost \\ Semeniuk LN, Voronkova NM, Larina OV}

Purpose of the study - to improve the methods of prevention, diagnosis and treatment of patients with history of early reproductive loss.

Materials and methods. During 2010-2017 study of the endometrium of women of reproductive age with an early history of reproductive loss (4-12 weeks) was performed. In the process of preparation for the next pregnancy, an evaluation of anti-inflammatory therapy was carried out after elimination of hormonal violations, genetic diseases and at least 3 months after the end of the last pregnancy. Ultrasound examination of the pelvic organs, histological and microbiological examination of the endometrium was carried out on the 7-10th and 21-24th days of the menstrual cycle.The contingent of studies was determined by retrospective analysis of the case histories of 360 women with 
spontaneous abortion in gestational terms from 5 to 12 weeks. Depending on the form of abortion, the groups were selected: $1(n=72)$ - anembryonia, 2 $(n=192)$ - embryo lysis, 3 ( $n=96)$ - frozen pregnancy on a background of the inflammatory process in the uterus. The control group consisted of 30 patients with artificial abortions, planning a future pregnancy.

Results and discussion. As a result of a retrospective analysis of histological studies of scrapers, various abnormalities in the development of pregnancy in the early period were observed. At the stage of preparation for pregnancy, an ultrasound evaluation of the structure of the endometrium in 100 women was performed. Among them, in group 1 there were 17 women who had anembryonia in anamnesis. Sonographically, the structure of the endometrium had some peculiarities: in 13 (76.47\%) cases, it satisfied the criteria for the 1st and 2nd phases of the menstrual cycle. Four women in the first stage had a hyperechoic structure of the basal layer, a decrease in the thickness of the endometrium (up to $6.3 \mathrm{~mm}$ ) in the 2 nd phase of the menstrual cycle and asymmetry (23.5\%). All patients underwent bacteriological and PCR studies of aspiration materials from the uterus. Conditionally pathogenic microorganisms were detected in $24.2 \%$, a combination of mycoplasma and ureaplasma in $15.2 \%$, a combination of mycoplasma, ureaplasma and viruses in $12.1 \%$, aero-anaerobic associations in $12.1 \%$, a combination of chlamydia and viruses in $61 \%$ cases.The study allowed to conduct etiopathogenetic treatment on the basis of changes revealed in each specific case.In patients with a predominance of viral and infectious factors, the immunomodulator was administered into the uterine cavity up to $5 \mathrm{ml}$ every 2 days, No. 5.The choice of the antibacterial drugs depended on the microbiological data.After the end of anti-inflammatory and immunomodulatory therapy, the microflora of the genital tract was restored by administering probiotics for 3 weeks. The duration of therapy was 4 weeks. Cyclic hormone therapy or only progestins in the II phase of the cycle was carried out for 2-3 cycles.Two months after the treatment, the control of its effectiveness was monitored. In the last cycle, the state of the endometrium was evaluated (ultrasound and hemodynamic dopplerometry of the uterus).As a result, the frequency of detection of the correspondence of the endometrium to the echographic structure during the secretory phase of the cycle was brought to the values of the control indices of healthy women of childbearing age.Evaluation of the restoration of fertility was carried out 6 months after the examination and treatment. The frequency of occurrence and progression of pregnancy for 12 weeks in the first group was 5 (29.41\%) cases compared with $18(47.36 \%)$ in group 2, $15(27.27 \%)$ in group3.

Conclusion. Chronic endometritis is a clinical and morphological syndrome, which is determined by ultrasonic criteria, and the morphological picture isequally important part of the diagnosis. Hysteroscopy can be considered as the final diagnostic method for establishing the pathology of the endometrium. Our results show a high percentage of chronic inflammation of the uterine cavity in patients with early reproductive losses.The results of hysteroscopic, microbiological and ultrasound studies can individualize therapeutic tactics. Conducted morphological studies demonstrated a high informative value of biopsy in the diagnosis of endometrial pathology.

Key words: lost pregnancy, endometrium, gestation 